\title{
Prediction of metabolizable energy values in poultry offal meal for broiler chickens
}

\author{
Edney Pereira da Silva ${ }^{1}$, Carlos Bôa-Viagem Rabello ${ }^{1}$, Luiz Fernando Teixeira Albino ${ }^{2}$, Jorge \\ Victor Ludke ${ }^{3}$, Michele Bernardino de Lima ${ }^{1}$, Wilson Moreira Dutra Junior ${ }^{1}$ \\ ${ }^{1}$ Departamento de Zootecnia, Universidade Federal Rural de Pernambuco, Dom Manoel de Medeiros, s/n, CEP: 52171-900, Recife, \\ Pernambuco, Brasil. \\ 2 Departamento de Zootecnia, UFV. \\ ${ }^{3}$ Embrapa - Suínos e Aves.
}

\begin{abstract}
This research aimed at generating and evaluating prediction equations to estimate metabolizable energy values in poultry offal meal. The used information refers to values of apparent and true metabolizable energy corrected for nitrogen balance (AMEn and TMEn) and for chemical composition of poultry offal meal. The literature review only included published papers on poultry offal meal developed in Brazil, and that had AMEn and TMEn values obtained by the total excreta collection method from growing broiler chickens and the chemical composition in crude protein (CP), ether extract (EE), mineral matter (MM), gross energy (GE), calcium (Ca) and phosphorus (P). The general equation obtained to estimate AMEn values of poultry offal meal was: AMEn $=-2315.69+31.4439(\mathrm{CP})+29.7697(\mathrm{MM})+0.7689(\mathrm{GE})-$ 49.3611(Ca), $\mathrm{R}^{2}=72 \%$. For meals with high fat contents (higher than 15\%) and low mineral matter contents (lower than $10 \%)$, it is suggest the use of the equation AMEn $=+3245.07+46.8428(\mathrm{EE}), \mathrm{R}^{2}=76 \%$, and for meals with high mineral matter content (higher than $10 \%$ ), it is suggest the equations $A M E n=4059.15-440.397(\mathrm{P}), \mathrm{R}^{2}=82 \%$. To estimate values of TMEn, it is suggested for meals with high mineral matter content the equation: TMEn = 5092.57 - 115.647(MM), $\mathrm{R}^{2}=78 \%$, and for those with low contents of this component, the option is the equation: TMEn $=3617.83-15.7988(\mathrm{CP})-$ 18.2323(EE) - 96.3884(MM) + 0.4874(GE), $\mathrm{R}^{2}=76 \%$.
\end{abstract}

Key Words: apparent metabolizable energy, broiler chickens, prediction equation, true metabolizable energy

\section{Predição dos valores de energia metabolizável da farinha de vísceras de aves para frangos de corte}

\begin{abstract}
RESUMO - Objetivou-se com esta pesquisa gerar e avaliar equações de predição para estimar os valores de energia metabolizável da farinha de vísceras de aves. As informações utilizadas referem-se aos valores de energia metabolizável, aparente e verdadeira, corrigidos para o balanço de nitrogênio (EMAn e EMVn) e à composição química das farinhas de vísceras de aves. A revisão de literatura incluiu apenas trabalhos publicados sobre farinha de vísceras de aves, desenvolvidos no Brasil, e que traziam os valores de EMAn e EMVn obtidos pelo método de coleta total de excreta com frangos de corte industrial em crescimento e a composição química em proteína bruta (PB), extrato etéreo (EE), matéria mineral (MM), energia bruta (EB), cálcio (Ca) e fósforo (P). A equação geral obtida para estimar os valores EMAn da farinha de vísceras foi: EMAn = -2315,69 $+31,4439(\mathrm{~PB})+29,7697(\mathrm{MM})+0,7689(\mathrm{~EB})-49,3611(\mathrm{Ca}), \mathrm{R}^{2}=72 \%$. Para farinhas com altos teores de gordura (acima de $15 \%$ ) e baixos de matéria mineral (abaixo de 10\%), recomenda-se utilizar a equação EMAn $=+3245,07+46,8428(\mathrm{EE})$, $\mathrm{R}^{2}=76 \%$ e, para altos teores de matéria mineral (acima 10\%), recomenda-se a equação: EMAn = 4059,15 - 440,397(P), $\mathrm{R}^{2}=82 \%$. Para estimar os valores EMVn, sugere-se para farinhas com elevado teor de matéria mineral: $\mathrm{EMVn=5092,57-}$ 115,647(MM), $\mathrm{R}^{2}=78 \%$ e, para aquelas com baixos teores deste componente, a opção é a equação: $\mathrm{EMVn=3617,83-}$ $15,7988(\mathrm{~PB})-18,2323(\mathrm{EE})-96,3884(\mathrm{MM})+0,4874(\mathrm{~EB}), \mathrm{R}^{2}=76 \%$.
\end{abstract}

Palavras-chave: energia metabolizável aparente, energia metabolizável verdadeira, equação de predição, frangos de corte

\section{Introduction}

Due to variability in the chemical composition of poultry offal meal, researches and nutritionists have faced difficulties in using this ingredient in rations, regarding the ideal levels of use and which nutrition matrix to use when formulating.

Albino \& Silva (1996) proposed that the use of prediction equations in determining energy values in animal-origin food is a viable and practical alternative to 
correct the variants in the composition of these ingredients, which are inherited from the production process and that adjust well to routine quality control procedures in the companies.

A total of 22 prediction equations of energy values in poultry offal meal was found in this review. From this total, eight predict the energy value in the apparent metabolizable energy system corrected for nitrogen balance, and the other fourteen predict the real metabolizable energy system, also corrected for the nitrogen balance. Both energy partition systems are intrinsically different, primarily because of the attainment methodology and, implicitly because of the bird age physiological effect on energy use, demonstrated by the same category used in each method.

It is also observed that the number of variables considered in the prediction method is of great value, since it is necessary that the variable to be predicted (v) assumes correlations with more simple and routine laboratory analysis, being idealized and monovariate.

However, this is not always possible. Such fact may be found in equations by Pesti et al. (1986) and by Robbins \& Firman (2006), in which one depends on a calorimeter and the other on an atomic absorption spectrophotometer.

Sophisticated and onerous equipments are necessary for using some prediction equations; a far-away reality for most ration plants in Brazil. Therefore, this research aimed at generating and evaluating prediction equations to estimate poultry offal meal metabolizable energy values for broilers in function of the chemical composition from literature data.

\section{Material and Methods}

The information used in this work refers to apparent and true metabolizable energy values, corrected for nitrogen balance (AMEn and TMEn), and chemical composition of poultry offal meals. The data used in this work came from a meticulous bibliographic review in order to include as many scientific articles, indexed or not, as possible by researching congress and symposiums annals, dissertations and theses.

The literature review only included published works on poultry offal meals developed in Brazil. Mixed ingredients, such as flour, feather and offal, and pig by-products meal, were not included in this cataloging once this procedure intended to isolate the variations relevant to the studied ingredient, in order to obtain as much information as possible and to reduce errors that could influence data analysis, as well as increase the information provided by the reliability of the equations.
In doing so, only the works that presented AMEn and TMEn values obtained by using the traditional method of collecting total excreta from growing broiler chickens, and the chemical composition in terms of crude protein (CP), ether extract (EE), mineral matter (MM), gross energy (GE), calcium (Ca) and phosphorus (P), were privileged and used. Those which did not present such information were grouped and analyzed separately.

Accordingly, the predominant pieces of information were crude protein and ether extract, as shown by all the studied works. About 20 pieces of information presented mineral matter and gross energy, in addition to these two variables. Only 17 complete pieces of information, which presented calcium and phosphorus values added to the other variables (crude protein, ether extract, mineral matter, gross energy, calcium, phosphorus), were collected. Regarding the energy system, all works expressed in AMEn, and 12 out of the 27 pieces of information cataloged also announced the by-products meal energetic value in TMEn (Table 1).

After the review, the obtained pieces of information were tabbed and received statistical treatment by applying the multiple regression analysis principles. Before this procedure to nullify the effects of humidity in the byproduct meal, the correction for the same dry basis of crude protein, ether extract, mineral matter, gross energy, calcium and phosphorus content, by adjusting the values to $92 \%$ of dry matter, was carried out, as suggested by Dale et al. (1993).

Besides the significance and determination coefficient $\left(\mathrm{R}^{2}\right)$ of each proposed model, the simulation of each equation predicted value, using the above-mentioned chemical composition, contrasted with the energetic value determined by metabolic essays, was carried out, and, through the mean square of the deviants between the determined value and the predicted value, the information on each model accuracy was obtained by the following equation:

$$
\left(\mathrm{DMQ}=\Sigma(\mathrm{VD}-\mathrm{VP})^{2} / \mathrm{N}\right]
$$

in which: $\mathrm{DMQ}=$ deviants mean square; $\mathrm{VD}=$ value determined in metabolic essay; $\mathrm{VP}=$ value predicted by the regression equation and; $\mathrm{N}$ = number of observations used to generate the equation.

The determination of prediction equations of AMEn and TMEn values were carried out by simple and multiple linear regression, using the indirect elimination technique (Backward) with the aid of the software Genetic and Statistical Analysis System-SAEG, version 9.1 (UFV, 2006). 


\section{Results and Discussion}

The results of the chemical composition and metabolizable energy of poultry offal meal complied with the attendance of the first premise for the elaboration of prediction equations, which praise the existence of variation in the chemical composition and metabolizable energy variables (Table 1 ).

Thereby, it is possible to observe that the highest and the lowest variation coefficient presented by the analyzed variables were 52.07 and $10.66 \%$ for calcium and gross energy, respectively, a characteristic considered to be desirable by some authors (Table 2) (Nunes et al., 2001; Rodrigues et al., 2002; Borges et al., 2003).

Nascimento et al. (2009), when working with corn grains, observed that the variations in the chemical composition were insufficient to enable the adjustment of a sole equation to predict, accurately, the energetic value of this ingredient at issue.

The variation present in contents of mineral matter, calcium and phosphorus was the highest among the cataloged variables and, especially, for these mineral elements. In literature, a calcium:phosphorus ratio in which higher levels of calcium in the by-products meal prevail is praised. In Brazilian works, this ratio is even narrower (1.36:1) when compared to foreign by-product meal (1.8:1), according to Silva (2009).

These ratios are in accordance with the mean chemical composition of the bones; however, the contents vary depending on the type of the bone and animal species. The mineral substances correspond to $38 \%$ of the bone and they are composed essentially by calcium phosphate (85\%), calcium carbonate (10\%), magnesium phosphate (1.5\%) and calcium fluoride (0.5\%), according to Roque (1996).

Dicalcium phosphate, the main component, is found as hydroxyapatite, which has the molecular formula described by $\mathrm{Ca}_{10}\left(\mathrm{PO}_{4}\right)_{6}(\mathrm{OH})_{2}$, which represents, in molar mass, a calcium:phosphorus ratio of $1.67: 1$, according to Oliveira (2005). Nonetheless, it was observed in this work an inverse calcium:phosphorus ratio, indicating prevalence of the phosphorus levels.

The variations of the other variables corroborated with the ones present in literature, such as the proportion of parts regarding meat and bones quantity, which affects the protein:mineral matter ratio. Therefore, the better the meat used by the mechanized systems, the better the mineral matter proportion in the by-products meal in the bone (Silva, 2009).

Table 1 - Means of chemical composition and energy values in poultry offal meal (POM) presented by different authors ${ }^{1}$

\begin{tabular}{|c|c|c|c|c|c|c|c|c|}
\hline Authors & $\begin{array}{c}\text { Crude } \\
\text { protein } \\
(\%)\end{array}$ & $\begin{array}{c}\text { Ether } \\
\text { extract } \\
(\%)\end{array}$ & $\begin{array}{c}\text { Gross } \\
\text { energy } \\
(\%)\end{array}$ & $\begin{array}{c}\text { Mineral } \\
\text { matter } \\
(\%)\end{array}$ & $\begin{array}{l}\text { Calcium } \\
\text { (\%) }\end{array}$ & $\begin{array}{c}\text { Phosphorus } \\
(\%)\end{array}$ & $\begin{array}{c}\text { AMEn } \\
(\mathrm{kcal} / \mathrm{kg})^{2}\end{array}$ & $\begin{array}{c}\text { TMEn } \\
(\mathrm{kcal} / \mathrm{kg})^{2}\end{array}$ \\
\hline Bellaver at al. (2001) POM 1 & 51.97 & 18.15 & & & & & 3530 & \\
\hline Bellaver at al. (2001) POM 2 & 51.53 & 17.76 & & & & & 4121 & \\
\hline Bellaver at al. (2001) POM 3 & 47.14 & 24.54 & & & & & 3874 & \\
\hline Bellaver at al. (2001) POM 4 & 46.29 & 20.76 & & & & & 3369 & \\
\hline Bellaver at al. (2001) POM 5 & 45.22 & 21.19 & & & & & 3638 & \\
\hline Bellaver at al. (2001) POM 6 & 50.23 & 20.83 & & & & & 4036 & \\
\hline Nascimento et al. (2002) POM 1 & 55.78 & 13.22 & 5381 & 15.15 & 3.12 & 2.04 & 3648 & 3233 \\
\hline Nascimento et al. (2002) POM 2 & 57.47 & 12.40 & 4777 & 13.00 & 3.22 & 3.51 & 3836 & 3645 \\
\hline Nascimento et al. (2002) POM 3 & 47.04 & 10.06 & 3755 & 24.74 & 3.31 & 2.85 & 2811 & 3541 \\
\hline Nascimento et al. (2002) POM 4 & 48.55 & 13.70 & 4171 & 21.64 & 2.89 & 2.08 & 3192 & 2289 \\
\hline Nascimento et al. (2002) POM 5 & 57.46 & 14.03 & 4824 & 12.43 & 3.49 & 3.57 & 3519 & 2898 \\
\hline Paula et al. (2002) & 58.01 & 16.99 & 5161 & 6.93 & & & 3663 & \\
\hline Tucci et al. (2003) & 58.76 & 11.04 & 4544 & 14.61 & & & 3517 & \\
\hline D’Agostini et al. (2004) & 66.17 & 18.91 & 5725 & 3.08 & 0.40 & 1.89 & 4346 & \\
\hline Soares et al. (2005) & 64.77 & 11.26 & 4660 & 13.24 & & & 3132 & 3158 \\
\hline Nery (2005) & 49.91 & 14.28 & 4525 & 10.11 & 3.03 & 2.49 & 2750 & \\
\hline Nunes et al. (2005) & 46.25 & 12.30 & 3822 & 24.38 & 9.52 & 3.98 & 2360 & \\
\hline Brumano et al. (2006) & 60.98 & 20.27 & 5062 & 10.94 & 4.73 & 2.32 & 3250 & \\
\hline Nunes et al. (2006) POM 1 & 49.71 & 16.35 & 4497 & 19.20 & 3.54 & 3.05 & 2730 & 2536 \\
\hline Nunes et al. (2006) POM 2 & 49.43 & 18.53 & 4468 & 19.48 & 5.38 & 2.73 & 2726 & 2460 \\
\hline Nunes et al. (2006) POM 3 & 59.92 & 13.38 & 4864 & 13.10 & 2.07 & 2.21 & 3089 & 3240 \\
\hline Mello et al. (2009) POM 1 & 56.83 & 15.54 & 4911 & 13.03 & 5.36 & 1.60 & 3631 & \\
\hline Mello et al. (2009) POM 2 & 60.59 & 15.47 & 5253 & 13.74 & 5.15 & 1.91 & 3910 & \\
\hline Ramalho (2008) & 54.95 & 10.61 & 5136 & 11.74 & & & 2524 & \\
\hline Silva (2009) POM 1 & 65.26 & 15.20 & 5116 & 10.03 & 2.47 & 1.35 & 3938 & 3957 \\
\hline Silva (2009) POM 2 & 68.76 & 11.40 & 4972 & 9.41 & 2.77 & 1.51 & 3746 & 3770 \\
\hline Silva (2009) POM 3 & 56.03 & 22.98 & 5591 & 11,74 & 3.14 & 1.71 & 4209 & 4229 \\
\hline
\end{tabular}


The variation for the ether extract might be linked to the manner it is processed, regarding fat increase in the digester for frying by-product meal, as well as its integrity on its mean of transportation: if it is by channels with the use of water, or by coil, or even by the use of conveyor belts (Maffi, 1993).

The correlations are showed according to the separation used in data analysis. These groupings were: $1^{\text {st }}$ - poultry offal meal; $2^{\text {nd }}$ - low energy by-product meal; and $3^{\text {rd }}$ - high energy by-product meal (Table 3). Overall, the first group significantly correlated to the plotted variables, except for the ether extract content.

In the second group, the crude protein and phosphorus levels were the variables with the highest correlation coefficient with corrected apparent metabolizable energy. It was expected that the mineral matter also showed this behavior, since this variable demonstrated a high negative correlation with gross energy; however, the interaction with the metabolizable energy was not significant. For the third group, the gross energy and the ether extract provided highly significant correlations.

For the correlation coefficients with the corrected real metabolizable energy, among the four correlated variables (crude protein, ether extract, mineral matter and gross energy), the ether extract was the only variable in which no significance was observed.

The low correlation of the ether extract with the other chemical components of the by-products meal might be explained by the fat proportion added into the digester, since there has not been a pattern to be followed by the companies yet. Besides, there is also the recovery rate of the fat present in the by-products meal (already existent + added) in its pressing procedure.

Concerning to the apparent and true metabolizable energy, the ether extract did not present neither a high nor a significant correlation for both cases; except for cases in which only the information of by-product meal with high contents of metabolizable energy was considered (Table 4). On the other hand, the by-product meals that presented high contents of mineral matter showed lower values of metabolizable energy in all cases, regardless to the system (apparent or real), thus showing an antagonistic correlation: the bigger the content of mineral matter, the smaller the value of metabolizable energy will be.

The ratio observed for the mineral matter was not noticed with the ether extract, thus some by-product meal presented high fat contents, but did not present high values of metabolizable energy. The low correlation coefficient with the metabolizable energy presented for the ether extract may be related, primarily, to the quality of this fat, and the interaction with metallic ions in the intestinal lumen.

On the topic on quality, the information generated from the burning in the calorimetric bomb of the fat present in the by-products meal is accounted in its totality. However, in metabolism essays, this energetic source is not assimilated with the same linearity by the animal. Therefore, Racanicci et al. (2004) concluded that lipid oxidation causes deep alterations in viscera fat of poultries. These authors found a reduction in metabolizable energy values close to $1,470 \mathrm{kcal} / \mathrm{kg}$ when fat was oxidized.

For interactions with metallic ions, high levels of fatty acids and calcium in the intestinal lumen, imposed by the replacement methodology recommended by Matterson et al. (1965) to evaluate the food, may lead to successive saponification reactions and the formation of insoluble soaps during the digestion, resulting in a decrease in the absorption of fatty acids, as it is suggested in the studies of Lessire et al. (1985). The calcium contents presented low correlation with the gross energy and even lower with the ether extract. Because of this lack of correlation, the variability without precedents in any of the used data is pointed out.

Table 2 - Chemical and energy composition in poultry offal meal

\begin{tabular}{|c|c|c|c|c|c|}
\hline & $\begin{array}{c}\text { Number of } \\
\text { observations }\end{array}$ & Mean & Maximum & Minimum & $\begin{array}{l}\text { Coefficien of } \\
\text { variation (\%) }\end{array}$ \\
\hline Crude protein (\%) & 27 & 55.00 & 68.76 & 45.22 & 12.30 \\
\hline Ether extract (\%) & 27 & 15.97 & 24.54 & 10.06 & 25.28 \\
\hline Calcium (\%) & 17 & 3.74 & 9.52 & 0.40 & 52.07 \\
\hline Phosphorus (\%) & 17 & 2.40 & 3.98 & 1.35 & 32.29 \\
\hline Gross energy (\%) & 21 & $4,819.79$ & $5,724.67$ & $3,755.02$ & 10.66 \\
\hline $\begin{array}{l}\text { True metabolizable energy } \\
\text { corrected for the nitrogen } \\
\text { balance }(\mathrm{kcal} / \mathrm{kg})\end{array}$ & 12 & $3,246.2$ & $4,229.2$ & $2,289.1$ & 18.90 \\
\hline
\end{tabular}


Overall, as the number of variables in the model increased, the adjustments of the prediction equations improved (Tables 5 and 6). Nunes et al. (2001) and Rodrigues et al. (2002) also observed a behavior similar to this one. These authors corroborate with the hypothesis that the best procedure would be keeping the adjustment with the decrease of variable numbers in the model, once this situation would decrease the need of laboratorial analysis.

For the prediction of values of corrected apparent metabolizable energy, 24 models were significant. Out of those, 11 were adequate to estimate the poultry offal meal metabolizable energy described by Rostagno et al. (2005). The equation that used all these variables was the following: $\left(\right.$ TMEn $_{(\mathrm{kcal} / \mathrm{kg})}=-2049.99+24.3107(\mathrm{CP})-18.1908(\mathrm{EE})+$
25.7792(MM) + 0.8674(GE) $-40.8754(\mathrm{Ca})-14.9818(\mathrm{P}) \mathrm{R}^{2}$ de $67.08 \%$ ). This equation allowed the highest detachment of the values determined in the metabolism essays. Phosphorus was the first variable to be eliminated by the Backward. However, the following monovariated equation, dependent on the crude protein $\left(\operatorname{AMEn}_{(\mathrm{kcal} / \mathrm{kg})}=1749.44+\right.$ 30.8831(CP), $\mathrm{R}^{2}=15.06 \%$ ), presented lower data adjustments.

Among the models, equation 3: $\left(\mathrm{AMEn}_{(\mathrm{kcal} / \mathrm{kg})}=-2315.69\right.$ $+31.4439(\mathrm{CP})+29.7697(\mathrm{MM})+0.7689(\mathrm{GE})-49.3611(\mathrm{Ca})$ with $\mathrm{R}^{2}$ of $71.90 \%$ ) enabled a higher adjustment and, consequently, a lower deviant in relation to the other equations. The simulation using the chemical composition extracted from the above-mentioned authors proved that this equation has an approximation to the recommended

Table 3 - Correlation analysis among AMEn and the studied variables

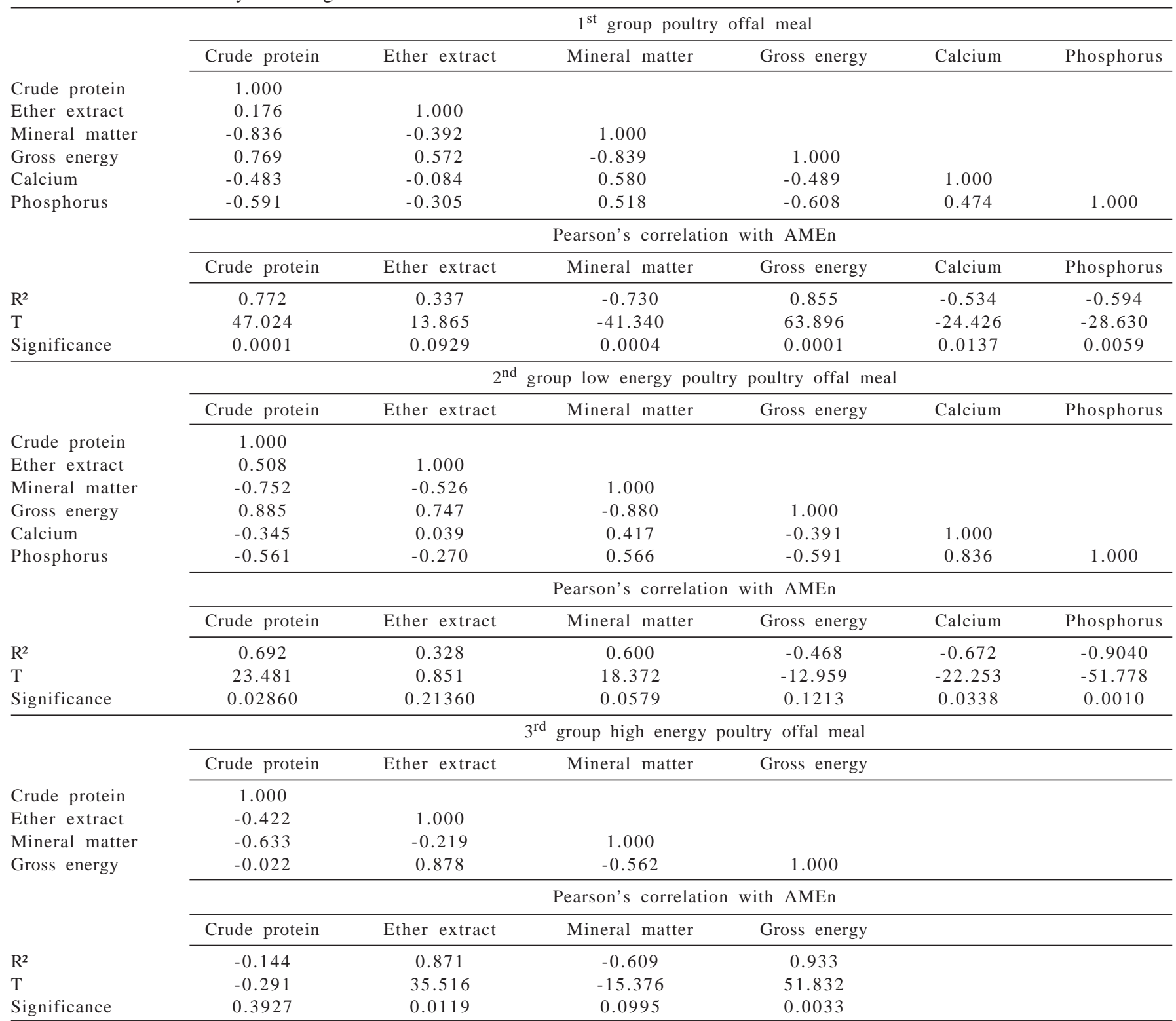

$\mathrm{R}^{2}=$ adjusted value; $\mathrm{T}=$ value test $\mathrm{T}$. 
value of $98.5 \%$. Nevertheless, although this equation presents a better adjustment, it brings the dependency on sophisticated equipments, such as the calorimetric bomb and a spectrophotometer.

The by-product meals that presented high energy values were grouped, and six models were created. The maximal, mean and minimal values for AMEn, CP, EE, CE and MM were: 4,346; 3,997 and 3,746 kcal/kg; 69, 62 and 56\%; 23, 16 and $11 \%$; 5,725, 5,239 and 4,777 kcal/kg; 14,10 and $3 \%$, respectively. Thereby, equation 17 enabled a good adjustment of the data and it reunited feasibility in its execution, since it is monovariate dependent of the ether extract, being: $\mathrm{AMEn}_{(\mathrm{kcal} / \mathrm{kg})}=+3245.07+46.8428(\mathrm{EE})$ with $\mathrm{R}^{2}$ of $75.92 \%$. By applying the maximal (23\%), mean (16\%) and minimal values (11\%), announced for the ether extract in this equation, deviants lower than $1 \%$ were found, i.e, $99 \%$ of reproducibility of the values measured in the metabolism essays.

For the low metabolizable poultry offal meal, six models were significant at $5 \%$ and one at $10 \%$. The six equations had phosphorus as the predictor variable and one monovariate, according to the model $\operatorname{AMEn}_{(\mathrm{kcal} / \mathrm{kg})}=$ $4059.15-440.397(\mathrm{P})$ with $\mathrm{R}^{2}$ of $81.71 \%$. In the simulation with the highest and the lowest catalogued phosphorus content, the equation predicted an error of 2.33 and $1.58 \%$ in the corrected real metabolizable energy value estimative.

However, the mean square of the residue was lower for the equation that did not have this variable in the model and it was significant at $10 \%$. This equation (24) only has crude protein content as the predictor variable, according to the model AMEn $n_{(\mathrm{kcal} / \mathrm{kg})}=+1392.33+27.5474(\mathrm{CP}), \mathrm{R}^{2}=36.74 \%$. This model is more sensitive for by-product meal with high mineral matter content because crude protein was significantly correlated with this variable $(r=-0.752)$ and with gross energy $(r=0.885)$, replicating the value determined

Table 4 - Correlation analysis between TMEn and the studied variables

\begin{tabular}{|c|c|c|c|c|}
\hline \multirow{6}{*}{$\begin{array}{l}\text { Crude protein } \\
\text { Ether extract } \\
\text { Mineral matter } \\
\text { Gross Energy }\end{array}$} & \multicolumn{4}{|c|}{ Poultry offal meals } \\
\hline & $\begin{array}{c}\text { Crude } \\
\text { protein }\end{array}$ & $\begin{array}{c}\text { Ether } \\
\text { extract }\end{array}$ & $\begin{array}{c}\text { Mineral } \\
\text { matter }\end{array}$ & $\begin{array}{c}\text { Gross } \\
\text { energy }\end{array}$ \\
\hline & \multicolumn{4}{|l|}{1.000} \\
\hline & -0.149 & \multicolumn{3}{|l|}{1.000} \\
\hline & -0.892 & -0.177 & \\
\hline & 0.651 & 0.439 & \multicolumn{2}{|l|}{-0.791} \\
\hline & \multicolumn{4}{|c|}{ Pearson's correlation with TMEn } \\
\hline & $\begin{array}{c}\text { Crude } \\
\text { protein }\end{array}$ & $\begin{array}{c}\text { Ether } \\
\text { extract }\end{array}$ & $\begin{array}{c}\text { Mineral } \\
\text { matter }\end{array}$ & $\begin{array}{c}\text { Gross } \\
\text { energy }\end{array}$ \\
\hline $\mathrm{R}^{2}$ & 0.7721 & 0.2371 & -0.896 & 0.8401 \\
\hline $\mathrm{T}$ & 3.6451 & 0.7323 & -6.0546 & 4.6462 \\
\hline Significance & 0.0027 & 0.2413 & 0.0001 & 0.0006 \\
\hline
\end{tabular}

$\mathrm{R}^{2}=$ adjusted value; $\mathrm{T}=$ value test $\mathrm{T}$. by biological essays in $98.2 \%$ of the metabolizable energy of the by-products meal with $18 \%$ of mineral matter.

For the corrected real metabolizable energy value prediction (Table 6), four models were generated. Mineral matter was present in all of them, once it presented significant correlation ( $\mathrm{p}=0.0001$ ) with the corrected real metabolizable energy ( $\mathrm{r}=-0.895)$. The lowest mean residual square was observed for equation 1: $\operatorname{TMEn}_{(\mathrm{kcal} / \mathrm{kg})}=\mathrm{D} 3617.83-$ 15.7988(CP)-18.2323(EE) - 96.3884(MM) + 0.4874(GE), $\mathrm{R}^{2}=75.51 \%$.

This model was accurate for the by-product meal that showed the lowest presence of mineral matter in its composition. In the by-product meals with mineral matter contents of 24.9; 15.7 and 9.5\%, the deviants were $7.1 ; 2.4$ and $1.9 \%$, respectively, demonstrating a peculiarity in the prediction. On the other hand, equation $4, \mathrm{EMVn}_{(\mathrm{kcal} / \mathrm{kg})}=$ 5092.57-115.647(MM) with $\mathrm{R}^{2}$ of 78.10\%, for these same byproduct meals (24.9; 15.7 and $9.5 \%$ of mineral matter), predicted an error estimated in 3.8; 4.1 and 7.5\%, respectively.

Nascimento (2000) elaborated six prediction equations for AMEn of poultry offal meal, in which it is necessary the determination of the average geometrical diameter in four of them, and, in for the other two equations, the data used in this work is applied since they predict a better application in by-product meal with high mineral matter content. By applying the model of better adjustment in by-products meals with 24 and $9 \%$ of mineral matter, it was found errors of 0.15 and $9.2 \%$.

The equations for TMEn prediction determined with roosters by Pesti et al. (1986) are more accurate for byproduct meals with low mineral matter contents (9\%), and the deviant was close to $0.5 \%$; however, for the by-product meals high in mineral contents, the estimative by the equation is $22.8 \%$ far from the determined value.

Dale et al. (1993), in 22 samples of by-product meal, observed that the lowest value determined from ether extract was $18.3 \%$, and the highest was $39.4 \%$. The real metabolizable energy values determined for these by-product meals were 3,626 and $5,247 \mathrm{kcal} / \mathrm{kg}$, respectively. By using the equation obtained for the high energy by-products meal, the estimate values corresponded to almost $87 \%$ for the by-pass meal with $18 \%$ of fat, and $97 \%$ of the value of the by-product meal that had 39.4\% ether extract.

Thus, it is evident that a single prediction equation cannot accurately predict the energey values of all types of by-product meal existing in the market. It is clear that there is a need for further studies to increase database, so some relations that have already been discussed can be elucidated, and some biological correlation coefficients can also be improved. 


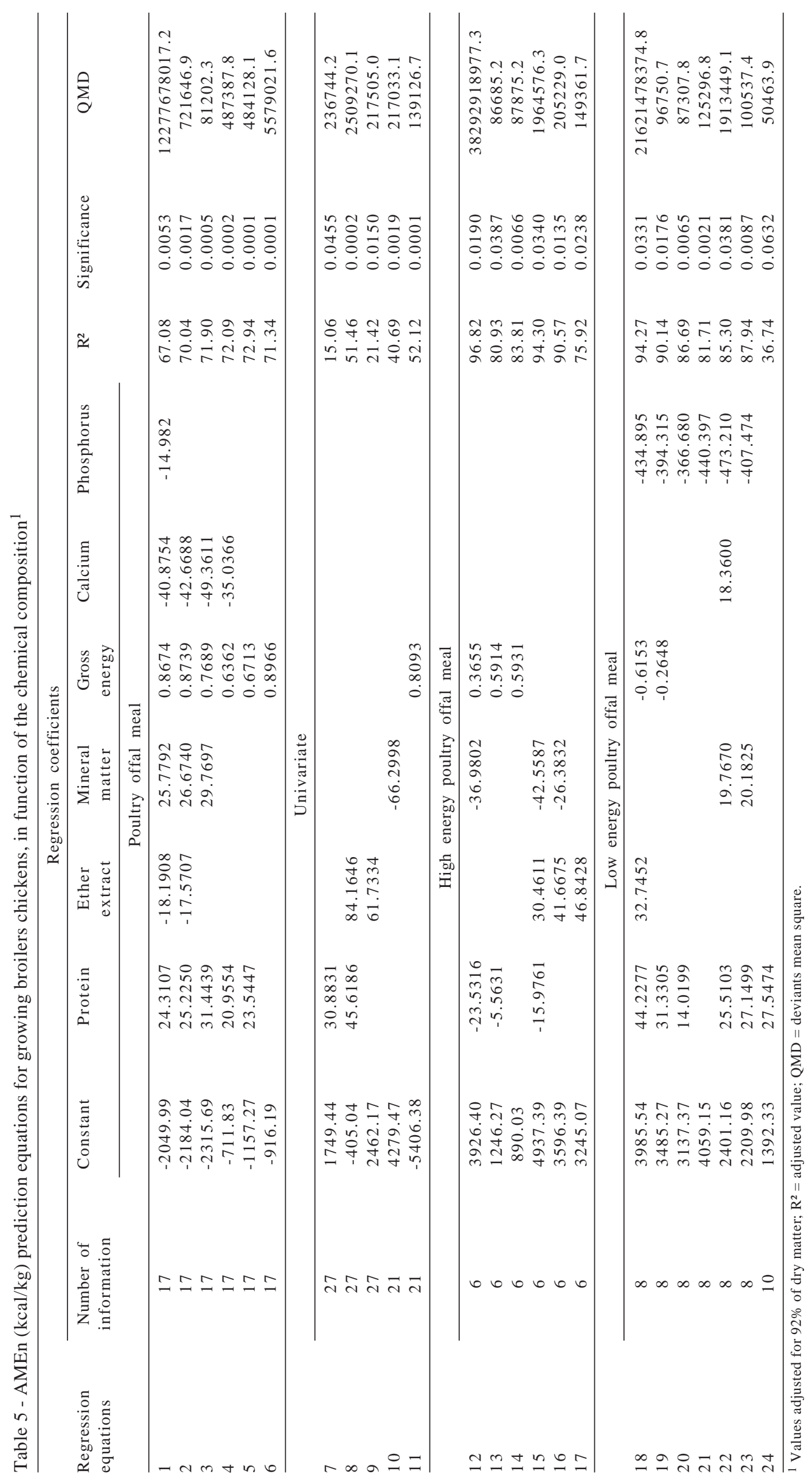

R. Bras. Zootec., v.39, n.10, p.2237-2245, 2010 
Table 6 - TMEn (kcal/kg) prediction equations for growing broilers chickens in function of the chemical composition ${ }^{1}$

\begin{tabular}{|c|c|c|c|c|c|c|c|c|c|}
\hline \multirow[t]{2}{*}{ ER } & \multirow[t]{2}{*}{ No. } & \multicolumn{8}{|c|}{ Regression coefficients } \\
\hline & & Constant & Protein & Extract & Matter & Gross energy & $\mathrm{R}^{2}$ & Significance & DMS \\
\hline 1 & 12 & 3617.83 & -15.7988 & -18.2323 & -96.3884 & 0.4874 & 75.51 & 0.0113 & 633205.0 \\
\hline 2 & 12 & 2413.94 & & -6.6823 & -77.7099 & 0.4575 & 78.58 & 0.0029 & 645657.0 \\
\hline 3 & 12 & 2513.40 & & & -79.8113 & 0.4223 & 81.14 & 0.0005 & 650709.0 \\
\hline 4 & 12 & 5092.57 & & & -115.647 & & 78.10 & 0.0002 & 848717.0 \\
\hline
\end{tabular}

${ }^{1}$ Values adjusted for $92 \%$ of dry matter; ER = regression equation; No = number of information; $\mathrm{R}^{2}=$ adjusted value; DMS = deviant mean square.

\section{Conclusions}

The overall equation obtained to estimate AMEn values of by-products meal is: AMEn $=-2315.69+$ $31.4439(\mathrm{CP})+29.7697(\mathrm{MM})+0.7689(\mathrm{GE})-49.3611(\mathrm{Ca})$, $\mathrm{R}^{2}=72 \%$. For by-product meals with high fat contents (above 15\%) and low mineral matter contents (below 10\%), the equation $\mathrm{AMEn}=+3245.07+46.8428(\mathrm{EE}), \mathrm{R}^{2}=76 \%$ is recommended and, for high mineral matter contents (above $10 \%$ ), the equation $\mathrm{AMEn}=4059.15-440.397(\mathrm{P}), \mathrm{R}^{2}=82 \%$ is recommended. To estimate TMEn values, the equation TMEn $=5092.57-115.647(\mathrm{MM}), \mathrm{R}^{2}=78 \%$ is recommended for by-products meals with high mineral matter contents (above 10\%) and, for low levels of this chemical component (below 15\%), it is recommended the equation TMEn = 3617.83 - 15.7988(CP) - 18.2323(EE) - 96.3884(MM) + $0.4874(\mathrm{GE}), \mathrm{R}^{2}=76 \%$.

\section{Acknowledgements}

The authors thank Pró-Reitoria de Pesquisa e PósGraduação of the Universidade Federal Rural de Pernambuco for effective supporting on the publication this article.

\section{References}

ALBINO, L.F.T.; SILVA, M.A. Valores nutritivos de alimentos para aves e suínos determinados no Brasil. In: SIMPÓSIO INTERNACIONAL SOBRE EXIGÊNCIAS NUTRICIONAIS DE AVES E SUÍNOS, 1996, Viçosa, MG. Anais... Viçosa, MG: UFV, 1996. p.361-388.

BELLAVER, C.; BRUM P.A.R.; LIMA, G.M.M. et al. Estimativas da energia metabolizável e dos coeficientes de digestibilidade dos aminoácidos de 20 farinhas de vísceras de aves. Revista Brasileira de Ciência Avícola, supl. 3, p.46, 2001.

BORGES, F.M.O.; ROSTAGNO, H.S.; SAAD, C.E.P. et al. Equações de regressão para estimar valores energéticos do grão de trigo e seus subprodutos para frangos de corte, a partir de análises químicas. Arquivo Brasileiro de Medicina Veterinária e Zootecnia, v.55, n.6, p.734-746, 2003.

BRUMANO, G.; GOMES, P.C.; ALBINO, L.F.T. et al. Composição química e valores de energia metabolizável de alimentos proteicos determinados com frangos de corte em diferentes idades. Revista Brasileira de Zootecnia, v.35, n.6, p.2297-2302, 2006.
D’AGOSTINI, P.; GOMES, P.C.; ALBINO, L.F.T. et al. Valores de composição química e energética de alguns alimentos para aves. Revista Brasileira de Zootecnia, v.33, n.1, p.128-134, 2004

DALE, N.; FANCHER, B.; ZUMBADO, M. et al. Metabolizable energy content of poultry offal meal. Journal Applied Poultry Research, v.2, n.1, p.40-42, 1993.

LESSIRE, M.; LEQUERCQ, B.; CONAN, L. et al. A methodological study of the relationship between the metabolizable energy values of two meat meals and their level of inclusion in the diet. Poultry Science, v.64, n.9, p.1721-1728, 1985.

MAFFI, G.L. Graxarias e subprodutos. In: CONFERÊNCIA APINCO DE CIÊNCIAS E TECNOLOGIA AVÍCOLAS, 1993, Santos. Anais... Santos: Fundação APINCO de Ciências e Tecnologia Avícolas, 1993. p.191-201.

MATTERSON, L.D.; POTTER, L.M.; STUTZ, M.W. The metabolizable energy of feed ingredients for chickens. Agricultural Experimental Station Research Report, v.7, p.3-11, 1965.

MELLO, H.H.C.; GOMES, P.C.; ROSTAGNO, H.S. et al. Valores de energia metabolizável de alguns alimentos obtidos com aves de diferentes idades. Revista Brasileira de Zootecnia, v.39, n.5, p.863-868, 2009.

NASCIMENTO, A.H. Determinação do valor nutritivo da farinha de vísceras e da farinha de penas para aves, utilizando diferentes metodologias. 2000. 106f. Tese (Doutorado em Zootecnia) - Universidade Federal de Viçosa, Viçosa, MG.

NASCIMENTO, A.H.; GOMES, P.C.; ALBINO, L.F.T. et al Composição química e valores de energia metabolizável das farinhas de penas e vísceras determinados por diferentes metodologias para aves. Revista Brasileira de Zootecnia, v.31, n.3, p.1409-1417, 2002. (supl.).

NASCIMENTO, G.A.G.; RODRIGUES, P.B.; FREITAS, R.T.F. Equações de predição para estimar os valores energéticos de alimentos concentrados de origem vegetal para aves utilizando a metanálise. Revista Brasileira de Zootecnia, v.38, n.7, p.1265-1271, 2009.

NERY, L.R. Valores de energia metabolizável e de aminoácido digestível de alguns alimentos para aves. 2005. $87 \mathrm{f}$ Dissertação (Mestrado em Zootecnia) - Universidade Federal de Viçosa, Viçosa, MG.

NUNES, R.V.; ROSTAGNO, H.S.; ALBINO, L.F.T. et al. Composição bromatológica, energia metabolizável e equações de predição da energia do grão e de subprodutos do trigo para pintos de corte. Revista Brasileira de Zootecnia, v.30, n.3, p.785-793, 2001.

NUNES, R.V.; POZZA, P.C.; NUNES, C.G.V. et al. Valores energéticos de subprodutos de origem animal para aves. Revista Brasileira de Zootecnia, v.34, n.4, p.1217-1224, 2005.

NUNES, R.V.; ROSTAGNO, H.S.; GOMES, P.C. et al. Valores energéticos de diferentes alimentos de origem animal para aves. Revista Brasileira de Zootecnia, v.35, n.4, p.1752-1757, 2006 (supl.)

OLIVEIRA, M.E. Potencial de inibição da progressão de cárie artificial por irradiação subablativa com laser de $\mathrm{CO}_{2}$ pulsado em esmalte dental bovino. 2005. 84f. Dissertação (Mestrado em Tecnologia Nuclear) - Instituto de Pesquisas Energéticas e Nucleares, São Paulo. 
PAULA, A.; BRUM, P.A.R.; AVILA, V.S. et al. Valores de energia metabolizável da farinha de carne e ossos e farinha de vísceras determinados com diferentes níveis de substituição para frangos de corte. Revista Brasileira de Agrociência, v.8, n.1, p.51-55, 2002.

PESTI, G.M.; FAUST, L.O.; FULLER, H.L. et al. Nutritive value of poultry by-product meal. 1. Metabolizable energy values as influenced by method of determination and level of substitution. Poultry Science, v.65, n.12, p.2258-2267, 1986.

RACANICCI, A.M.C.; MENTEN, J.F.M.; REGITANO-D'ARCE, M.A.B. et al. Oxidação lipídica do óleo de vísceras de aves para redução de seu conteúdo de energia metabolizável para frangos de corte na fase de crescimento. Revista Brasileira de Zootecnia, v.33, n.4, p.919-923, 2004.

RAMALHO, V.R.R.A.R. Avaliação nutricional de subprodutos de abatedouros avícolas para frangos de corte. 2008. $133 \mathrm{f}$. Tese (Doutorado em Zootecnia) - Universidade Federal Rural de Pernambuco, Recife.

ROBBINS, D.H.; FIRMAN, J.D. Evaluation of the metabolizable energy of poultry by-product meal for chickens and turkeys by various methods. International Journal of Poultry Science, v.5, n.8, p.753-758, 2006.

RODRIGUES, P.B.; ROSTAGNO, H.S.; ALBINO, L.F.T. et al. Valores energéticos da soja e subprodutos da soja, determinados com frangos de corte e galos adultos. Revista Brasileira de Zootecnia, v.31, n.4, p.1771-1782, 2002.
ROQUE, V.F, Aproveitamento de resíduos de carne de frango: uma análise exploratória. 1996. 84f. Dissertação (Mestrado em Engenharia de Produção) - Universidade Federal de Santa Catarina, Florianópolis.

ROSTAGnO, H.S.; ALBINO, L.F.T.; DONZELE, J.L. et al. Tabelas brasileiras para aves e suínos - Composição de alimentos e exigências nutricionais. 2.ed. Viçosa, MG: UFV/DZO, 2005. v.1. $186 \mathrm{p}$.

SIBBALD, I.R.; PRICE, K. The effects of level of dietary inclusion and of calcium on the true metabolizable energy value of fats. Poultry Science, v.56, n.6, p.2070-2078, 1977.

SILVA, E.P. Estudo da farinha de vísceras de aves na ração de frangos de corte industrial sob os parâmetros: energético e nutricional. 2009. 135f. Dissertação (Mestrado em Zootecnia) - Universidade Federal Rural de Pernambuco, Recife.

SOARES, K.R.; BERTECHINI, A.G.; FASSANI, E.J. et al. Valores de energia metabolizável de alimentos para pintos de corte na fase préinicial. Ciência e Agrotecnologia, v.29, n.1, p.238-244, 2005.

TUCCI, F.M.; LAURENTIZ, A.C.; SANTOS, E.A. et al. Determinação da composição química e dos valores energéticos de alguns alimentos para aves. Acta Scientiarum.Animal Sciences, v.25, n.1, p.85-89, 2003.

UNIVERSIDADE FEDERAL DE VIÇOSA - UFV. SAEG - Sistema de análises estatísticas e genéticas. Versão 9.1. Viçosa, MG: UFV, 2006. (CD-ROM). 